\title{
COST EFFICIENCY OF APPLYING TRADE FINANCE FOR AGRICULTURAL SUPPLY CHAINS
}

\author{
Oleksandra Laktionova ${ }^{1}$, Oleksandr Dobrovolskyi ${ }^{2}$, ${ }^{*}$ Tatyana Karpova ${ }^{3}$, Andrey Zahariev ${ }^{4}$ \\ ${ }^{1}$ Prof. Dr. Vasyl Stus Donetsk National University. Vinnitsa, Ukraine. \\ Tel.+380502539011.E-mail: laktionova.loa@donnu.edu.ua \\ ${ }^{2}$ Assoc. Prof. PhD. Vasyl Stus Donetsk National University. Vinnitsa, Ukraine. \\ Tel.+380674309567. E-mail: dobrovolskyy456@gmail.com \\ ${ }^{3}$ Assoc. Prof. PhD. Vasyl Stus Donetsk National University. Vinnitsa, Ukraine. \\ Tel.+380990732700.E-mail: t.karpova@donnu.edu.ua \\ ${ }^{4}$ Prof., PhD. D.A. Tsenov Academy of Economics, Svishtov, Bulgaria \\ Tel. +359889882298. E-mail: andrey.zahariev.1971@gmail.com
}

Received 2901 2019; Accepted 08032019

\begin{abstract}
Agricultural enterprises are active participants of the trade finance market. Purchasing plant protection products, they take out a loan or pay off using promissory note. Today the schemes of interaction between participants, the services cost and other parameters are not well studied. The aim of research - to construct patterns interaction of the entities and explore the cost efficiency of alternative trade finance transactions, using DCF methodology. The research explores the schemes of interaction between agricultural producer, distributor and guarantor bank with promissory notes and bills of exchange. It is justified that a promissory note provides an additional income, bill of exchange increases the number of customers by granting a deferment. The financial scheme for producers without direct banking borrowing is proposed.

Key Words: agricultural supply chain, cost efficiency, effective interest rate, surety for bill of exchange, promissory note, trade finance.

JEL Classification: G21, G23, Q14.
\end{abstract}

\section{Introduction}

All enterprises use the borrowed funds to finance ongoing operations (trade finance). There are a lot of options for replenishment the working capital. Agricultural enterprises are active participants on trade finance market, especially for the acquisition of plant protection products. Financial agents offer to take advantage of credit or provide services for the promissory note, which was written out by agricultural producers in favor of the distributor of plant protection products. Choosing the best proposals relates to clearly understanding of interaction schemes between the participants, the cost of services and other parameters of transaction.

The issues of financing of agricultural business market participants are an important part of research by economists from different countries. The investigation

Copyright (C) 2019 The Authors. Published by Vytautas Magnus University, Lithuanian Institute of Agrarian Economics. This is an open access article distributed under the terms of the Creative Commons Attribution NonCommercial 4.0 (CC BY-NC 4.0) license, which permits unrestricted use, distribution, and reproduction in any medium, provided the original author and source are credited. The material cannot be used for commercial purposes.

* Corresponding author 
of funding instruments is committed in scientific works of Vargand and Sipiczki (2015), by expert researches Abbas and Nobanee (2017). The different approaches of government support for agriculture financing is observed by Mochalina (2014) and Alston (2010). The effectiveness of financial sector development is investigated by Ariuna Taivan (2018). The specific economic features of plant protection product market are examined by Gordeychuk (2015).

The features of bill of exchange and promissory note use are considered in the works of Belovski (2016) and Cambridge Law Journal (1930).

Payment schemes and interaction between participants in the implementation of availing operations of promissory note as payment are not popular. The promoting of this service is placed on the websites of commercial banks, distributors of plant protection products, market intermediaries and other information sites (Beshanov, 2000). It is emphasized that availing is much cheaper than credit both for agricultural producers and end consumers of plant protection products. Websites of banks even demonstrate financial savings on the example of these two operations, representing the arithmetic calculations of operational cost (Raiffeisen, 2018). This does not include such key financial categories as time value of money, tax protection, calculation of return through alternative transactions, additional income, proper accounting of transaction costs (Belovski, 2016).

The theory proves the usefulness of the non-cash transaction - availing bills as the financing option for agricultural sector. It doesn't give answer about the full cost of this transaction, basically considering it as promissory note of other economic agents. Little research has been taken to calculate the cost of plant protection products for producers with deferred and spot payment - the basis of the promissory note schemes.

The aim of the research is to construct the available patterns of economic agent's interaction in the process of implementation the procedure for availing of bills for plant protection products and to identify the proper methodology of calculation the cost efficiency of alternative transactions to bank credit.

In the article is used comparative analyses to examine alternative documentary tools, which allow to make payments between economic entities without direct transfer of funds during transaction. The debtor transfers the document to the lender in the form of a bank guarantee or bank's promissory note.

Method of calculation the effective interest rate is used to know the cost of alternatives. Using promissory note and bill of exchange can significantly reduce the borrower's costs, without the risk of non-payment, to sell the goods, to perform work or provide service to the seller.

It is studied the literature on trade finance, the trend of mutual settlements between suppliers and consumers of plant protection products. DCF methodology made it possible to measure the benefits and costs, taking into account possible risks, choosing a method of debt financing. The tax shield, the calculation of return through an alternative transaction, the opportunity to get additional income and transaction costs have considered as well. 
The research outcomes may be applied by the banks, officials, decisionmakers of public institutions that operate in agricultural sector, fiscal authorities, agricultural producers, customers.

\section{Results of research - advantages of applying trade finance for agricultural supply chains}

Retailers - distributors of famous brands that are engaged in the manufacture of plant protection products, fertilizers and other agricultural chemical products are active consumers of financial services (Varchenko, 2018). In Ukraine, this segment is represented by the worldwide agrochemical companies: "Basf", "Syngenta", "Adama" and others (fig. 1) (Import, 2018). The volume of sales of plant protection products in Ukraine is estimated by 10 thnds of tons monthly (fig. 2).

Given the fact that in Ukraine 47682 agricultural enterprises are active, the sales of chemistry products conduct on directly and through a distribution network (Pavlenko, 2018). Only the big companies like "Nibulon", whose demand for pesticides in 2014 amounted to 225 tons, imported plant protection products without intermediaries (Gordeichuk, 2015). The prompt and adequate financing for the producers is one of the most important factors of their success.

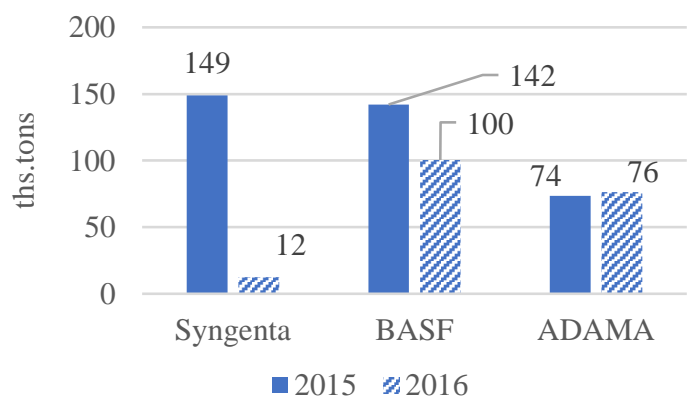

Figure. 1. Major suppliers of pesticides in Ukraine in 2015 - 2016

Source: Import of pesticides to Ukraine (2016)

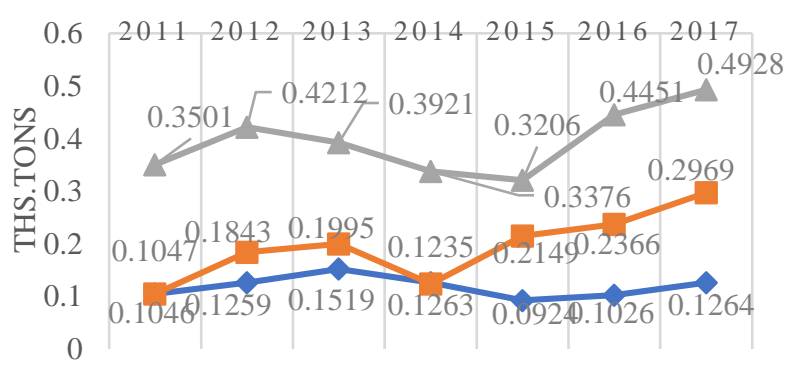

$\rightarrow$ insecticides $\rightarrow$-fungicides $\rightarrow$ herbicides

Figure. 2. Dynamics of import of pesticides to Ukraine in 2011-2017 Sourse: Import of pesticides to Ukraine (2011-2017)

For these purposes, Ukrainian agrarians use own and borrowed funds, involving banking institutions (direct lending, targeted programs, leasing arrangements, availing bills) (Shved, 2014) However, if we count the companies, offering specific bank loans, the weight of the bank financing is much higher because financial intermediaries like leasing and factoring companies finance their customers with bank sources, and this statement is at least half partly true for integrators as well (Varga, 2015). Using the promissory note scheme is a common payment option for plant protection products to distributor. This scheme has a number of advantages for the drawer and drawee. It provides the relationship between the drawer - agricultural 
producer, drawee - the distributor and the guarantor - the bank (fig. 3). The object of availing is monetary debt for this product in the form of promissory note.

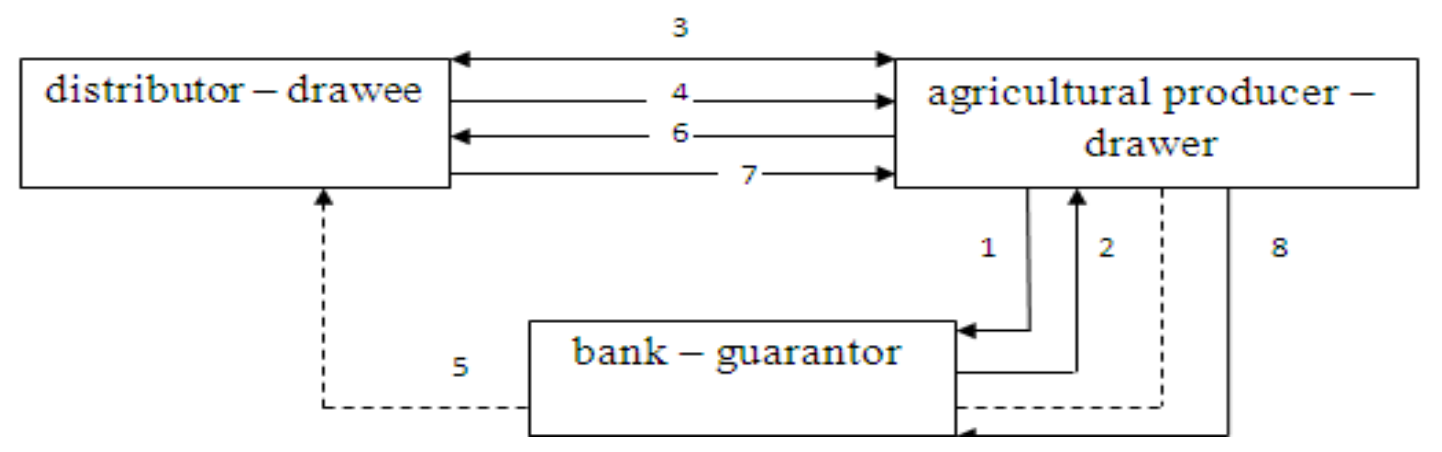

Figure 3. Scheme of promissory note availing of agricultural producer in favor of distributor

1. Producer's handling to bank, asking about the possibility of promissory note availing.

2. Obtaining a guarantee letter by producer for distributor bank. 3. Transferring a guarantee letter by producer to distributor and signing the delivery agreement. 4 . The distributor ships the goods and provides supporting documents. 5. Producer issues a promissory note, avails it and passes to distributor. 6. Producer pays a note in favor of distributor. 7. Returning the note by distributor to producer. 8. Submitting of repayment the promissory note to cover the debt by producer.

It is obvious that, in comparison with other participants the highest risk falls on the distributor, because the goods are shipped by the bank guarantee, in the form of promissory note. This supposes the passing by bank guarantor of accreditation in the distributor. When deciding on the possibility of bills availing, the commercial bank assesses not only the paying capacity of the drawer and other factors, but also liquidity provision. In case, if the drawee presents a bill for payment in due time and payment is not made by the drawer, the bank as guarantor will carry it out. Later, the bank asks appropriate amount from the drawer directly or through the implementation of any available provision. In exceptional cases, banks provide a guarantee for a bill payment without provision. In such cases, the commission for availing of bill raises. Distributor should consider the fact, if the surety is given for the acceptor or the drawer of promissory note, the protest to guarantor is not required. The bank may require the distributor to confirm the fact of handling with the requirement of payment or acceptance, and he can refuse. Although the scheme with a bank draft provides the acceptance before the surety is carried out. Bank-guarantor, that made the payment to the distributor realizes its right of penalty by way of regress. In fact, the guarantor has the right of regress claim against the person, for whom it is provided surety and all persons have obligations to person, as a joint and several debtors (Beshanov, 2000).

As well as exchange, bill may be used as a tool for calculating the delivered plant protection products. This scheme provides the transfer by the bank of availing bills of agricultural producer (fig. 4). In the case of the bill of exchange, guarantor should to examine not only the paying capacity of the drawee (debtor of agricultural producer), but also the drawer (agricultural producer). 


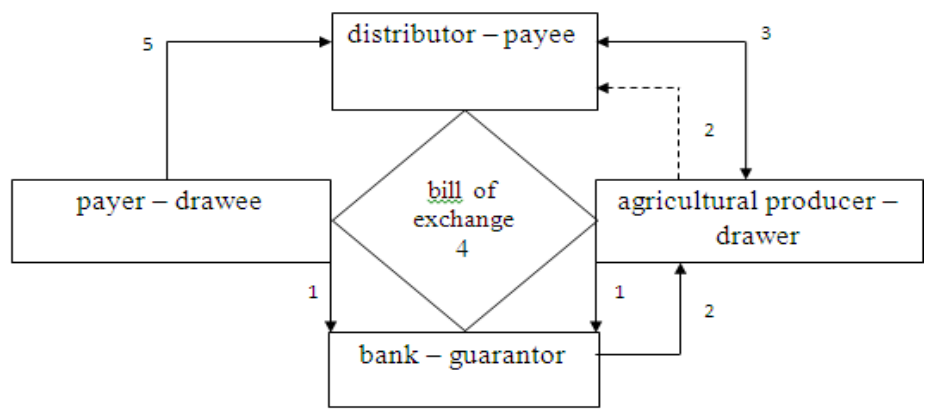

Figure 4. Scheme of availing bill of exchange of agricultural producer in favor of distributor

1. Handling of producers to bank asking about the possibility of bill of exchange availing. 2. Obtaining producer guarantee letter from bank and passing it to distributor. 3. Signing the delivery agreement between distributor and producer with the use of bill scheme. 4 . The drawer issues the bill of exchange (draft) in payee's favor, the drawee accepts it, bank guarantees. 5. The payer pays on a bill in distributor's favor no later than the due date.

Some agricultural producers have the opportunity to work with buyer of plant protection products on a prepayment basis. Such cooperation scheme (fig. 5) enables efficient use of payment. Producer has the ability to get revenue not only from trading, but also from the fund's investments. An important component of the transaction is the funds availability from the producer on bill payment date. Otherwise, the distributor may appeal against the bill. Additional income of agricultural producer may be calculated according to the following pattern:

$$
\text { Inc }=S_{i r r}-C_{a v}-C_{t}-C_{c}
$$

where: Inc is income from for the transaction according to fig. 5; $S_{\text {irr }}$ is sum of interest income on investments funds; $C_{a v}$ is costs on availing the bill; $C_{t}$ is costs for banking operations, including payments to third parties; $C_{c}$ is capital expenditures.

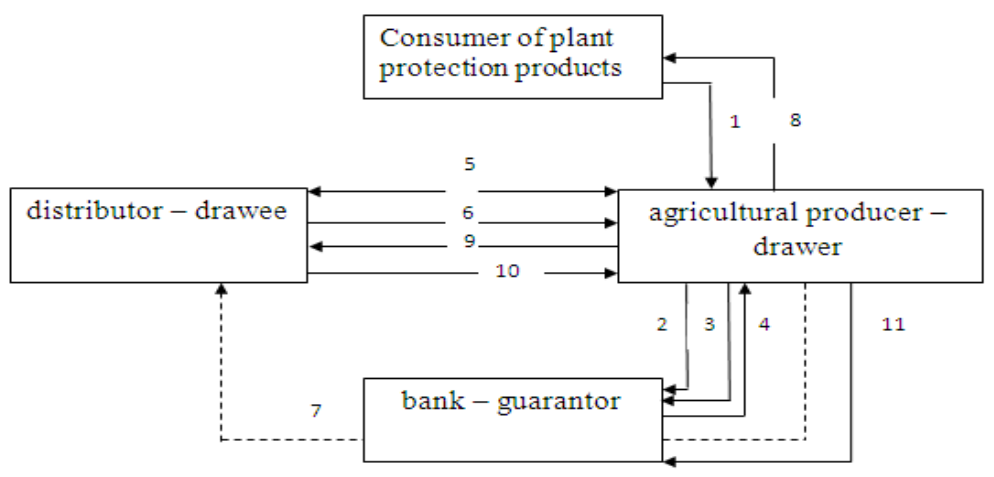

Figure. 5. Scheme of promissory note availing of agricultural producer in favor of distributor

1. Getting prepayment by producer from the consumer. 2. Investment of funds by producer 
for urgent or special account at bank. 3. Producer's handling to bank, asking about possibility of availing promissory note. 4 . Getting a guarantee letter by producers for distributor from bank. 5 . Sending a guarantee letter by producer to distributor and signing the delivery agreement. 6 . Shipment of goods by the distributor and providing the supporting documents to producer. 7 . Producer issues a promissory note, guarantees it in the bank and passes to the distributor. 8 . Shipment of the goods by producer to the consumer. 9. Producer pays the note in favor of the distributor no later than due date. 10. Returning the note by distributor to producer. 11. Providing of promissory note repayment by producer to bank to cover the debt and discharge the deposit.

The calculation should consider the time value of money concept. For some enterprises, the cost of the diversion funds (cost of capital) can be high and the transaction would be economically inefficient. Not all drawers are able to provide bill surety, especially in the form of cash cover. In this case, agricultural producers have to buy goods on a prepaid basis through their own or borrowed funds. Although in the absence of liquid collateral, it is challenging to attract debt capital.

On the other hand, customers, who have the good reputation in a competitive market, will be looking for such agricultural producer, deliver of the goods with deferred payment. The buyer receives a deferred payment, which corresponds to the agreed date of presentation for bill payment. The using of the following diagram on fig. 6 may solve the problem of purchase by producer without borrowings and increased working capital.

Correct completion of schemes with a promissory note and bill of exchange relates to the timely payment by the drawer and acceptor. Otherwise, the responsibility to repay the bills is transferred to the guarantor. The drawer can make payment in the scheme with drafts, which can 't be in automatic mode. This means that, if the collateral is cash coverage, the mortgagor need accumulate the required amount on the due date of bill payment. Like collateral, which the drawee provides to the bank, this can act as cash coverage and other real estate, personal property depending on the collateral guarantor policy.

The scheme on fig. 6 can increase market share and provide additional income for agricultural producer. So, promissory note provides additional income, and bill of exchange increases the number of consumers by providing a deferment. At its core, the bill availing is documentary resource-free transaction. Its total cost should correspond to the expected profit margins from credit. 


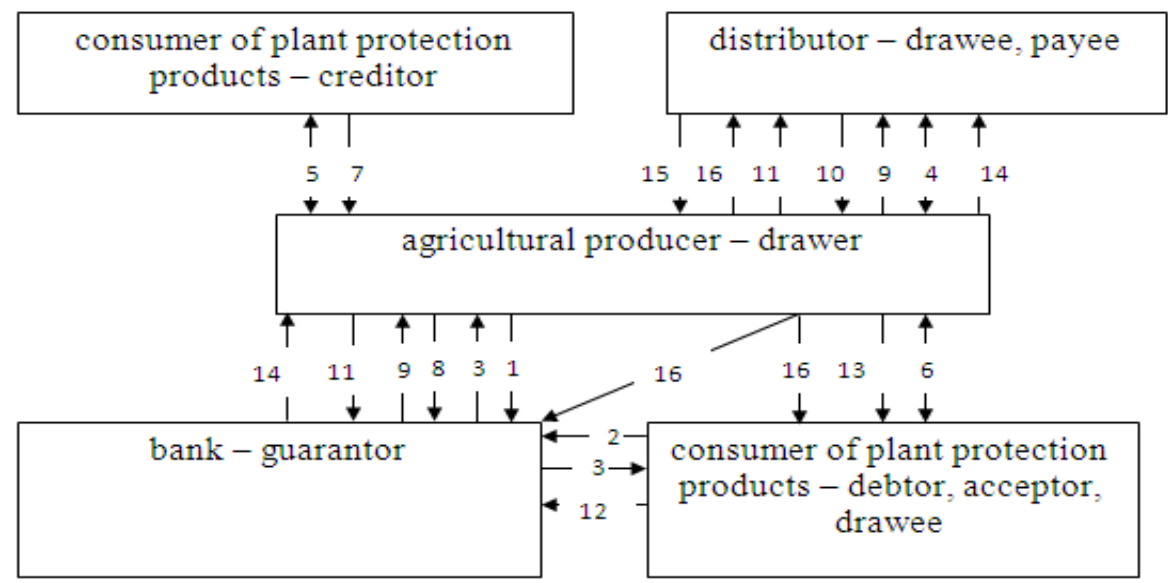

Figure 6. Purchasing scheme of plant protection products by agricultural producer without borrowings and additional working capital

1. The provision of documents by producer as a drawer for examining the possibility of availing transaction of promissory and bill of exchange. 2 . The provision of documents by consumer as the acceptor for examining the possibility of availing transaction of bill of exchange. 3 . The provision of the bank - the guarantor of indicative offer to producer and consumer about the possibility of carrying out transactions. 4. Signing of supply contract between producer and distributor with bill. 5. Signing of sale contract by creditor on a prepayment basis. 6 . Signing of sale contract between producer and consumer by debtor on credit terms. 7. Implementation of the prepayment by consumer to producer. 8. Investment of funds by producer. 9. Preparation of guarantee letter by producer to a bank distributor. 10. Shipment of goods by distributor and providing the supporting documents to producer. 11. Launching of producer's promissory note in favor of distributor. 12. Provision of security by consumer (acceptor) to the bank (guarantor) for availing bill of exchange transaction. 13. Supplying goods by drawer with a promissory note to the drawee, acceptor. 14. Getting a guarantee letter by producer to a bank distributor. 15. Shipment of goods by distributor and provision of supporting documents. 16. Launching of bill of exchange by drawer in favor of payee, its acceptance by consumer.

Obviously, the promissory note calculation scheme for agricultural producer is preferable to credit. To prove this fact, we can use the example (table 1):

Table 1 . The costs of credit and availing of the bill

\begin{tabular}{|l|l|}
\hline \multicolumn{1}{|c|}{ Availing of the bill } & \multicolumn{1}{c|}{ Bank Credit } \\
\hline limit $-1000000 \mathrm{UAH}(32258$ Euro) & limit - 1000000 UAH (32258 Euro) \\
\hline financing term -9 mo & financing term - 9 mo \\
\hline $\begin{array}{l}\text { fee for bill availing - 3\% one-time from the } \\
\text { limit }\end{array}$ & $\begin{array}{l}\text { interest rate }-18 \% \text { per annum, fee }-0,99 \% \text { one-time } \\
\text { from the limit }\end{array}$ \\
\hline $\begin{array}{l}\text { the cost of availing - 30000 UAH (967.7 } \\
\text { Euro) }\end{array}$ & the cost of financing - 144900 UAH (4674 Euro) \\
\hline
\end{tabular}

The calculation (table 1) shows, that the savings are about $144900 \mathrm{UAH}$. Although, detailed calculation requires comparing the effective rates for both transactions. To calculate the effective or internal rate of return cash, flows on credit and availing, we use formula - the basis for calculating the function XIRR of MS Excel. 


$$
0=\sum_{i=1}^{N} \frac{P_{i}}{(1+\text { rate })^{\frac{\left(d_{i}-d_{1}\right)}{365}}},
$$

where: $d_{i}-$ date of $i$ (last) payment; $d_{1}$-date of 0 payment (initial date); $P_{i}-$ amount of $i$ (last) payment.

Supposing that the borrower:

a) is subject of taxation on income of legal persons; b) may use the tax shield in the calculations; c) pays interest on the credit, which was accrued on the American system of charging interest (base 360 days and 30 days for each period) then, using the existing data for the calculation, the formula 2 is converted to the formula 3 :

$$
0=\sum_{i=0}^{N} \frac{C F_{\text {out }_{i}}-\frac{\left(S_{i} R_{i}+C_{a_{i}}\right) \cdot R T_{C}}{100}}{(1+r)^{\frac{30 \cdot i}{365}}}
$$

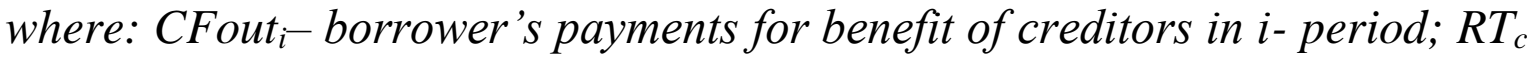
- income tax rate of legal entities in percentage terms; SIR - sum of percentages to be paid in i period; $\mathrm{Ca}_{i}$-related expenses; $N$-number of the last payment period; $r$ -(rate from formula 2) - the internal rate of return for a supplied series of cash flows.

The "zero" cash flow $\left(\mathrm{CF}_{0}\right)$ as a component of the calculation will be:

$$
C F_{0}=\frac{-C R+C R \cdot C_{a_{i}}}{(1+r)^{0}}
$$

where: $C R$ - the sum of the credit.

Using data from table 1, we reduce the calculated values in table 2. Thus, excluding the tax shield, $r=21.26 \%$. Taking into account the tax shield, zero flow is:

$$
C F_{0}=\frac{-C R+C R \cdot C_{a_{i}}-C R \cdot C_{a_{i}} \cdot R T_{c}}{(1+r)^{0}}=-991882 U A H,
$$

where: $r=17.13 \%$.

Table 2. The effective interest rate of credit

\begin{tabular}{|c|c|c|c|c|c|}
\hline \multirow{2}{*}{$(i)$, mo } & $\begin{array}{c}\left(C R_{i}\right), \text { Payment of the } \\
\text { principal sum of credit, } \\
U A H\end{array}$ & $\begin{array}{c}(\text { SIR } i), \text { Payment of } \\
\text { interest of credit, } \\
U A H\end{array}$ & $\begin{array}{c}\text { CFout, } U A H \\
C F_{\text {outi }} /(1+r)^{30^{*} / 360} \\
U A H\end{array}$ & $\begin{array}{c}\left(S I R_{i}\right) * R T_{c}, \\
U A H\end{array}$ \\
\hline 1 & 0.00 & 15000 & 15000 & 14761 & 12139 \\
\hline 2 & 0.00 & 15000 & 15000 & 14526 & 11980 \\
\hline 3 & 0.00 & 15000 & 15000 & 14294 & 11823 \\
\hline 4 & 0.00 & 15000 & 15000 & 14067 & 11669 \\
\hline 5 & 0.00 & 15000 & 15000 & 13843 & 11516 \\
\hline 6 & 0.00 & 15000 & 15000 & 13622 & 11365 \\
\hline 7 & 0.00 & 15000 & 15000 & 13405 & 11217 \\
\hline 8 & 0.00 & 15000 & 15000 & 13191 & 11070 \\
\hline 9 & 1000000 & 135000 & 1015000 & 878391 & 899104 \\
\hline Total & 1000000 & 1135000 & 990100 & 991882 \\
\hline
\end{tabular}


Due to calculation, availing has only two cash flows - the "zero" and the last. In this ninth stream - it is a direct payment in favor of the holder. Therefore, payment for this transaction will be $4.14 \%$, and $3.38 \%$ considering the tax shield.

It should be noted, that availing transaction costs affect only on payment of the transaction, while crediting the sum of financing is decreased. Based on the example of crediting, it will amount to $991882 \mathrm{UAH}$ of the required $1.000000 \mathrm{UAH}$. Economic benefit of availing is expressed in monetary terms and can be calculated using the formula 6 , it was proposed to select the alternative between financial leasing and credit:

$$
N P V_{\text {leasing }}=P V_{\text {leasing }}-\sum_{i=1}^{n} \frac{C F_{\text {leasing }}}{\left(1+r_{\text {credit }}\right)^{n}} \rightarrow N P V_{\text {aval }}=P V_{\text {aval }}-\sum_{i=1}^{n} \frac{C F_{\text {aval }}}{\left(1+r_{\text {credit }}\right)^{n}}
$$

Using the effective credit rate, we find that availing is "cheaper" than bank credit by 124710.09 UAH and considering the tax shield by 87224.29 UAH. Obviously, the promissory note scheme for agricultural producer is significantly more profitable compared to direct credit. This is due to a gross value of documentary transaction and the ability to grant an extension for the consumer of plant protection products without additional costs.

Consequently, agricultural producer may pretend for a discount for payment without deferment. The discount amount must be equal to lost revenue of the distributor. Supposing that such payment will be the interest rate for 9 monthly deposit with repayment of interest monthly. We reduce the deposit rate on the company tax. Thus, the interest income for the first 9 months would be:

$$
S I R D=\frac{C R \cdot I R D-C R \cdot I R D \cdot R T_{C}}{360} \cdot 30 \cdot 9,
$$

where: SIRD - interest revenue on deposit;

IRD - interest rate on deposit.

Therefore, the buyer or agricultural producer, who makes a payment on spot conditions, can suppose the discount (for our example -9.23\%). For a more visual representation of dependence of funding payment for agricultural producer from interest income on deposit of distributor it is necessary to convert formula 3 , adding income on deposit which was adjusted for income tax:

$$
\begin{aligned}
& 0=-\left(C R-C R \cdot C_{a}+C R \cdot C_{a} \cdot R T_{C}\right)+\sum_{i=1}^{N-1} \frac{\frac{C R \cdot I R \cdot 30}{360}-\frac{C R \cdot I R \cdot 30}{360} \cdot R T_{C}-\frac{C R \cdot I R D \cdot 30}{360}+\frac{C R \cdot I R D \cdot 30}{360} \cdot R T_{C}}{(1+r)^{\frac{30}{360}}}+ \\
& +\frac{\frac{C R \cdot I R \cdot 30}{360}-\frac{C R \cdot I R \cdot 30}{360} \cdot R T_{c}-\frac{C R \cdot I R D \cdot 30}{360}+\frac{C R \cdot I R D \cdot 30}{360} \cdot R T_{C}+C R}{(1+r)^{\frac{30 \cdot N}{360}}}
\end{aligned}
$$

where: IR - interest rate. 
For building a graph of dependence of payment (r) from the interest rate on the deposit (IRD), we write the corresponding function:

$$
I R D=I R-\frac{C R-C R \cdot C_{a}+C R \cdot C_{a} \cdot R T_{C}-\frac{C R}{(1+r)^{\frac{30 \cdot N}{360}}}}{\frac{C R \cdot 30}{360} \cdot\left(1-R T_{C}\right) \cdot\left(\sum_{i=1}^{N-1} \frac{1}{\left.(1+r)^{\frac{30 \cdot i}{360}}+\frac{1}{(1+r)^{\frac{30 \cdot N}{360}}}\right)}\right.}
$$

The dependence of credit payment of agricultural producer from the deposit income to distributor could be presented as liner function, for which we use the baseline values: $I R=0.18 ; C R=1000000 \mathrm{UAH} ; C_{a}=0.0099 ; R T_{c}=0.18 ; N=9$.

The main results from this relation may be identified as:

1) with increasing of the deposit interest rate of distributor (IRD), credit payment for agricultural producer is reduced (r);

2) credit payment is close to zero $(r=0)$, if the distributor can invest the borrowed funds of agricultural producer which were received as a payment for the delivered plant protection products with an interest rate higher than $19.2 \%$ per annum for 9 months with monthly interest;

3 ) if the distributor is not able to invest received funds from agricultural producer $(I R D=0)$, the payment $\mathrm{r}=17.13 \%$;

4) credit payment is equal to availing payment ( $\mathrm{r}=3.38 \%)$, while the interest rate on the deposit $I R D=15.5 \%$ per annum.

\section{Conclusions}

Despite the fact, that trade credit by bills availing is a relatively new tool in the Ukrainian market, the international organizations are interested in it. Plant protection products are expensive, but can increase productivity up to 50\%, and local farmers save on them (Kabash, 2012). In conclusion, the study can draw the following findings:

1. Financing programs of agricultural producers are quite popular in the financial market, because of their obvious cheapness in comparison with direct credit for working capital of agricultural producer.

2. The analysis of promissory notes proposals of agricultural producers compared with credit shows, that payment of credit is much higher. The promissory notes as well as bills of exchange are subject of availing. This allows to expand the boundaries of the resource-free payments between both of agricultural parties.

3. Considering, that not all the drawers can provide security for surety of the bill, and customers with good business reputation pretend to the deferment of payment, certain promissory note payment scheme has been designed. Parity is achieved with the simultaneous activation of promissory note and bill of exchange. Promissory note brings additional income for producer and bill of exchange gives a deferment for the customers. 
4. More advantages for both parties could be achieved if: a) the farmer with the distributor count on spot; b) payment is made at the expense of credit funds; c) the distributor deposits the received funds; d) the distributor provide a discount to the agricultural producer, which is equivalent to the deposit interest.

5. Availing is only one of the payment options in terms of developed banking system and market relations between agents and it may be replaced by a direct credit. The funds immediately bring greater added value and customer should receive a discount.

\section{References}

Abbas, F., Nobanee, H., Khan M., Varas, J. (2017) The Influence of Supply Chain Management and Net Trade Cycle on Financial Performance // International Journal of Supply Chain Management. № 4: 51-60

Alston, J.M., Andersen, M.A., James, J.S., Pardey, P.G. (2010) Persistence Pays: U.S. Agricultural Productivity Growth and the Benefits from Public R\&D Spending. - New York: Springer.

Ariuna Taivan (2018) Financial Development and Economic Growth Revisited: Time Series Evidence // International Journal of Trade, Economics and Finance, Vol. 9, № 3: 116-120.

Beshanov, V.A., Gaevoy, G.I., Avakov, A.B. (2000) Vekselnoe obrashenie: teoria i praktika. Kharkov, 382 p.

Gordeichuk, D., Kozachenko, L., Lissitsa, A. (2015) K chemu privedet dorogovizna SZR i udobreniy v Ukraine. Protection of plants. $31 \mathrm{p}$.

Import of pesticides to Ukraine (2011-2017).

http://ucab.ua/ua/doing_agribusiness/resursi_agrovirobnitstva/agrokhimiya [ $\left[\begin{array}{lll}11 & 12 & 2018\end{array}\right]$

Kabash, N. (2012). Farmers will be given $\$ 35$ million on availing of bills for the purchase of plant protection products Bayer. - http://www.aaa-agro.com/comments/9241.html [11 12 2018]

Mochalina, O. (2014). Problems of borrowed funds formation in agriculture of Ukraine // Agrosvit № 15: 8-15.

Raiffeisen Bank Aval. https://www.aval.ua/ru/corporate/special_for_agro/[[15 11 2018]

Pavlenko, I., Tverdova, I., Shibaykin, V., Marakova, A. (2018) Business mechanism of innovation-driven development of the agricultural market infrastructure // Economic Annals-XXI, 169 (1-2): 57-61.

Shved, Y. Apk-inform (2014). Vosstanovlenie rinka agrocreditovaniya stoit ozidat ne ranee osenney posevnoy 2015 goda - KPMG. - http://www.apk-inform.com/ru/exclusive/topic/1032021 [21 10 2018]]

S. R. L. (1930) Bill of Exchange, Drawee Not Named. Validity of Document as Promissory Note - Bills of Exchange Act, 1882 // The Cambridge Law Journal. № 4 (1): 53-54.

Varchenko, O., Svynous, I., Skotsyk, V., Grynchuk, Y., Khakhula, L. (2018) Price Parity of Reconstructing Technological Supply Chain Capacity in the Agricultural Sector of Ukraine // International Journal of Supply Chain Management. № 4: 397-406.

Varga, J \& Sipiczki, Z. (2015). The financing of the agricultural enterprises in Hungary between 2008 and 2011 // Procedia Economics and Finance: 923-931.

Belovski, V., Majhosev, A., Dujovska, I. (2016) The bill of exchange as a means of payment and security // Journal of Process Management - New Technologies, International. Vol.4, №3: 39-49. 


\title{
ŽEMĖS ŪKIO TIEKIMO GRANDINIŲ PREKYBOS FINANSAVIMO SĄNAUDŲ EFEKTYVUMAS
}

\author{
Oleksandra Laktionova ${ }^{1}$, Oleksandr Dobrovolskyi ${ }^{2}$, ${ }^{*}$ Tatyana Karpova ${ }^{3}$, Andrey Zahariev ${ }^{4}$ \\ 1,2,3 Donecko nacionalinis universitetas, ${ }^{4}$ Tsenov Ekonomikos Akademija
}

Gauta 201901 29; priimta 20190308

\begin{abstract}
Santrauka
Žemès ūkio įmonès aktyviai dalyvauja prekybos finansų rinkoje. İsigydami augalų apsaugos produktus, jie pritraukia paskolą arba sumoka su vekseliais. Šiandien dalyvių sąveikos, paslaugų kainos ir kitų sandorio parametrų schemos nepakankamai ištirtos. Straipsnio tikslas - suformuluoti subjektų sąveikos modeli ir ištirti alternatyvaus sandorio skaičiavimo ekonomini efektyvumą, taikant teorinę, empirinę ir DCF metodiką. Straipsnyje nagrinejjami žemès ūkio gamintojų, platintojų ir garantų banko sąveikos modeliai, naudojant vekselius. Patvirtinta, kad vekselis suteikia papildomų pajamų, vekselis padidina klientų skaičių, suteikdamas atidejjimą. Siūloma finansinè schema gamintojams, neturintiems tiesioginio skolinimosi.

Raktiniai žodžiai: žemès ūkio tiekimo grandinè, ekonominis efektyvumas, efektyvi palūkanu norma, garantija vekseliui, vekselis, prekybos finansavimas.

JEL kodai: G21, G23, Q14.
\end{abstract}

* Autorius pasiteirauti 